\title{
Diabetes Management and Control Using Yoga Prana Vidya (YPV) Healing System
}

\author{
Dr. Ashalatha H. Rajagopal MBBS \\ YPV Practitioner, Medical officer \\ Primary Health Centre, Gopanahalli, Hassan, Karnataka, India \\ Tel: +91-87488 66445 E-mail: ashalatha.hr123@ gmail.com \\ Ramya Ashwin BE (Computer Science) \\ YPV Practitioner, \\ Hassan, Karnataka, India \\ Tel: +91-8147062216 E-mail: Ramya_u1000@yahoo.com \\ Dr. Venkata S. Nanduri PhD (Corresponding author) \\ Consultant-Research \& Publications, Yoga Prana Vidya Ashram \\ Doddaubbanur, Hosur-Thally Road, Krishnanagar DT, TN, India \\ Tel: +919963101850Ｅ-mail: vsnanduri@yahoo.com
}

Received: June 27, 2019 Accepted: July 28, 2019

doi:10.5296/jbls.v10i2.15199 URL: https://doi.org/10.5296/jbls.v10i2.15199

\begin{abstract}
Yoga Prana Vidya (YPV), which is a non-touch non-drug biofield-energy healing method performed by trained YPV healers, is used successfully as complementary and also as alternative medicine to cure various human ailments, including diabetes.

The present study was carried out by analyzing data collected during three years from YPV healing camps in which diabetes patients were healed. The findings show that in the sample of 19 patients healed for type 2 diabetes, there was medically acceptable reduction of blood sugar level for some and appreciable decreased levels for all. This indicates that primarily the targeted YPV healing framework was effective and worked well in the management and
\end{abstract}


control of diabetes for the sample subjects.

YPV protocols used in healing Diabetes are examined in detail and YPV process framework and model are presented. The authors conclude that the evidence gathered in this study confirms successful outcome of YPV practice in the management and control of diabetes and offers scope for targeted research in future on bigger scale.

Keywords: YPV system of healing, diabetes type II treatment, diet, exercise, meditation, blood glucose levels

\section{Introduction}

Spiritual, Physical and Mental healing is practiced by all cultures from prehistory to present, but research on these practices and underlying mechanisms is in its infancy (Jonas \& Crawford, 2003). Yoga Prana Vidya (YPV) is an integrated system of healing based on ancient art and science adopted to modern ways of living and has been established to cure even some difficult medical conditions as an alternative medicine (Neravetla \& Nanduri, 2019).

Diabetes Mellitus (DM) worldwide is projected to rise to 552 million, representing $10 \%$ of global adult population, by 2030 up from 366 million in 2011. The burden is worse in the developing world which represents $80 \%$ of cases (Matheka \& Demaio, 2013).

The primary objective of this study is to gather evidence recorded in the YPV healing camps by examining the pattern of results obtained from the historical data of past 3 years (2016 2018) available with the Yoga Prana Vidya (YPV) Ashram to understand how effective is YPV system of Healing to manage and control Type 2 Diabetes. Also, this study aims to know if consistent results are obtained when different and independent healers (practitioners) perform YPV system of healing on patients of type 2 Diabetes under similar conditions.

\section{Literature Review}

\subsection{YPV System Theory, Principles and Practice}

Yoga Prana Vidya (YPV) is a no drug, no touch healing system (Yoga Prana Vidya Research, 2019) which uses Prana Shakti (life force), known as Bio-field energy in Science(Warber, Gordon, Gillespie, Olson \& Assefi, 2003), to heal all types of physical and psychological ailments. YPV is integrated and holistic system which improves the overall health and wellbeing of the people. Yoga Prana Vidya is not intended to replace the systems like Ayurveda, Homoeopathy, and Allopathy etc. (Yoga Prana Vidya Research, 2019). It works as complementary and also as an alternative medicine to these systems in many cases enhancing the natural healing power within our bodies at a faster rate with remarkable effect (Neravetla \& Nanduri, 2019). YPV primarily involves the healing of the Energy Body which interpenetrates and extends beyond the Physical Body by several inches (Fig 1) (Neravetla, 2019). 


\subsection{Literature Background}

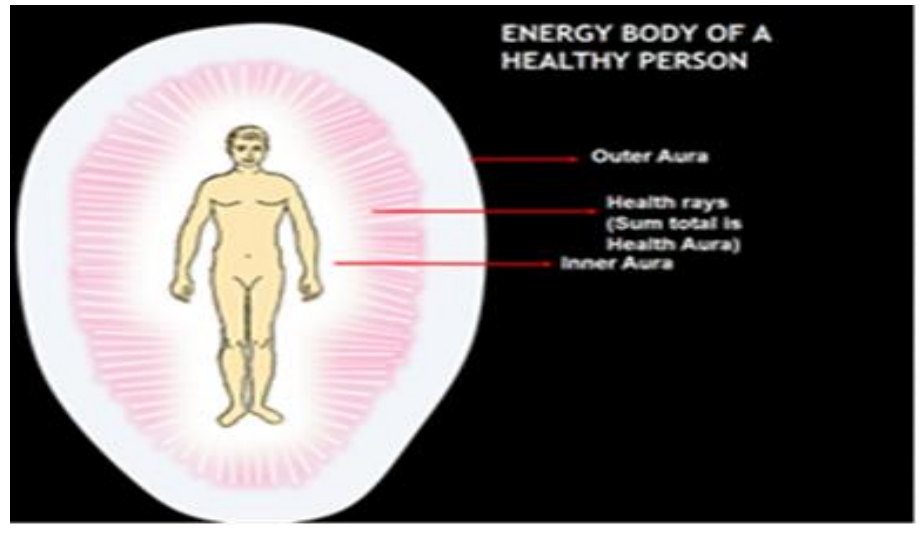

Figure 1. Energy body of a healthy person (Neravetla, 2019)

(Legend: Outer aura, Health rays between outer and inner auras, inner aura)

The Energy Body shown in Fig 1 is referred to as the Pranamaya Kosha in Sanskrit, Etheric Double in Theosophy and Bio-Plasmic Body by Modern Science. The energy body is considered to be made up of the fourth state of matter - the Bio-Plasma in Science. It consists of Outer Aura, Inner Aura and health rays in between.

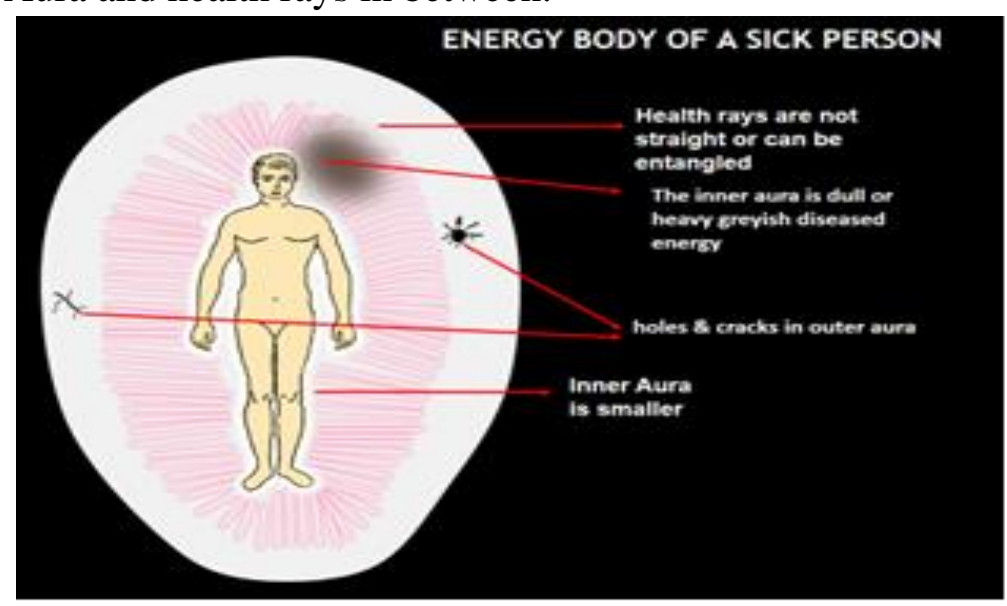

Figure 2. Energy body of a sick person (Neravetla, 2019)

(Legend: Health rays are not straight, or entangled; the inner Aura is dull or has heavy greyish diseased energy, holes and cracks in outer aura, and inner aura is smaller)

Sickness manifests as defects in the energy body as in Fig 2, such as holes, cracks and twisted health rays. These are not visible to naked eye, but sensed by hands of a trained and experienced healer. Healing of energy body enables healing the physical ailments.

In YPV, healing is done by cleansing, energizing and balancing the chakrams or energy centres present in the Energy Body. Various workshops on YPV System are available to learn this healing methodology. Figure 3 shows the computer generated GDV (Gas Discharge Visualisation) camera images of bio-plasmic energy field around the physical body before and after healing. 


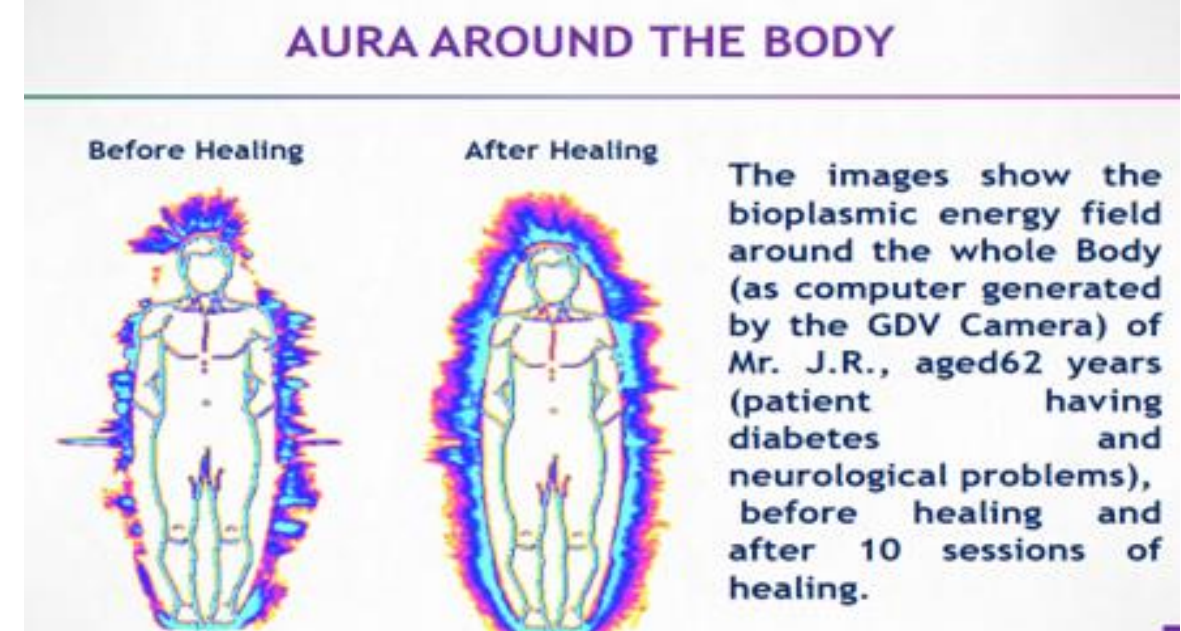

Figure 3. Aura Around the body - Before \& after healing (Neravetla, 2019)

Within the limited research literature available, several review articles on the science and art of energy healing (Yoga Prana Vidya Research, 2019), such as Wardha (2004), appeared in the literature. Some standards for Biofield energy research (Warber, S.L., Gordon, A., Gillespie, B.W., Olson, M \& Assefi, N. 2003) dealing with definitions of the terms used and suggested methods in research found in the literature. In addition to organic reasons, psychological factors seem to play a crucial role in causing and amplifying diabetes, and several studies found substantial correlation of psychological factors such as critical life events in causing Type 1 diabetes, PTSD (post-traumatic stress disorder) or depression in Type 2 diabetes (Markus, Martin, Lisa v \& Bernhd, 2018). Diabetes is among the commonly treated ailments using energy therapies such as Yoga Prana Vidya system of energy healing, and experience and available research show that the energy healing is effective in treating diabetes (Matheka \& Demaico 2013).

\section{Materials and Methods}

This is an exploratory study under qualitative regime of Research. Exploratory research, as the name implies, intends to explore the research questions/objectives and does not intend to offer final and conclusive solutions to existing problems. It has been noted that "exploratory research is the initial research, which forms the basis of more conclusive research (Research-Methodology.net, 2018).

\subsection{YPV Healing Practice Protocols Used in Diabetes Management and Control Interventions}

Integrated YPV Healing Approach (YPV Ashram, 2018a \& b) is made in case of treating Diabetes which involves rapidly increasing the natural healing ability of the body to heal itself. The steps stated below are followed to bring about improvement in the patient.

1. Physical Exercises including walking

This step consists of a cycle of simple yogic exercises of not more ten minutes duration that can be done conveniently any time of the day, but preferably, morning, noon and evening. These exercises are suitable to people of all ages 
generally above 10 years.

2. Rhythmic Yogic Breathing Exercise (RYB)

This is also known as abdominal breathing and consists of minimum 12 repetitive cycles of inhalation for 6 seconds, holding for 3 seconds, exhalation for 3 seconds and holding for 3 seconds (6-3-6-3).

3. Diet

YPV specifies vegetarian diet consisting of taking Isabgol (known as Psyllium in English) and green tea after waking up in the morning, fruit breakfast two to three hours thereafter, a salt-less midday meal, evening tea with light health snack, followed by either fruits or light supper at early night.

4. Planetary Peace Meditation (PPM)

Known earlier as meditation on twin hearts, this takes about 17 minutes.

5. Forgiveness Sadhana

This technique takes less than 5 minutes.

6. YPV Healing Technique

This consists of cycles of cleansing, energising and securing the Chakrams (Energy Centres) of the energy body, simultaneously repairing the holes and cracks in the energy body. Also healing is applied to affected body parts

YPV Healing involves balancing of energy body and chakrams (energy centres), which have both physical and psychological functions. It has processes of cleansing and energizing the affected parts and chakrams. YPV is successfully applied to both psychological healing and physical healing. First five points stated above are for patient self-practice for which training is given by the YPV healer-trainer. YPV Healing technique at point 6 is performed by the healer.

In some cases, patient may not follow / not be able to follow the points 1 to 5 , or some of them. In this event, the healers guide, motivate and help them to follow all the points based on their capacity and mobility. In general, patients themselves follow these better as they improve. In each individual healing, psychological healing is done in the beginning, followed by healing of energy body for healing the physical body.

The process of YPV healing by a trained healer consists of cleansing the chakrams and/or the affected parts/organs, energising the same and securing with hand gestures. The investigators carried out an analysis of the healing process used and carried out Identification of the steps and events in the process of YPV treatment and healing common to all healers that worked in treatment of diabetes patients. This study has enabled to generate a general framework and a process model of YPV system as shown below.

(A) An input- throughput-output type frame work is identified from the YPV system as 
shown in Figure 4 below.

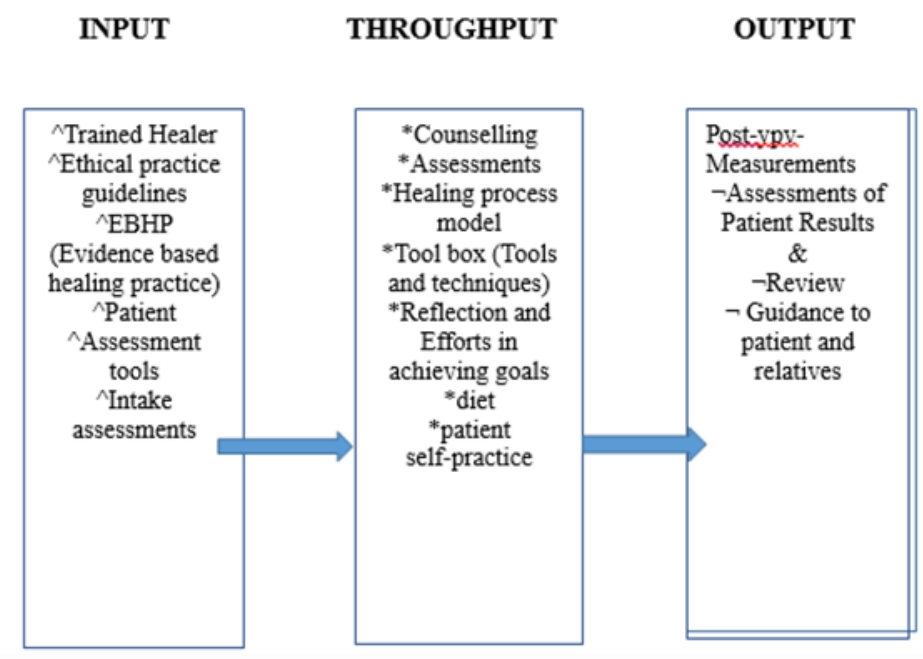

Figure 4. YPV system Healing Framework

From the above stated framework it can be observed that YPV is an integrated approach and it will enable treating the patient holistically managing various physical and mental ailments. 


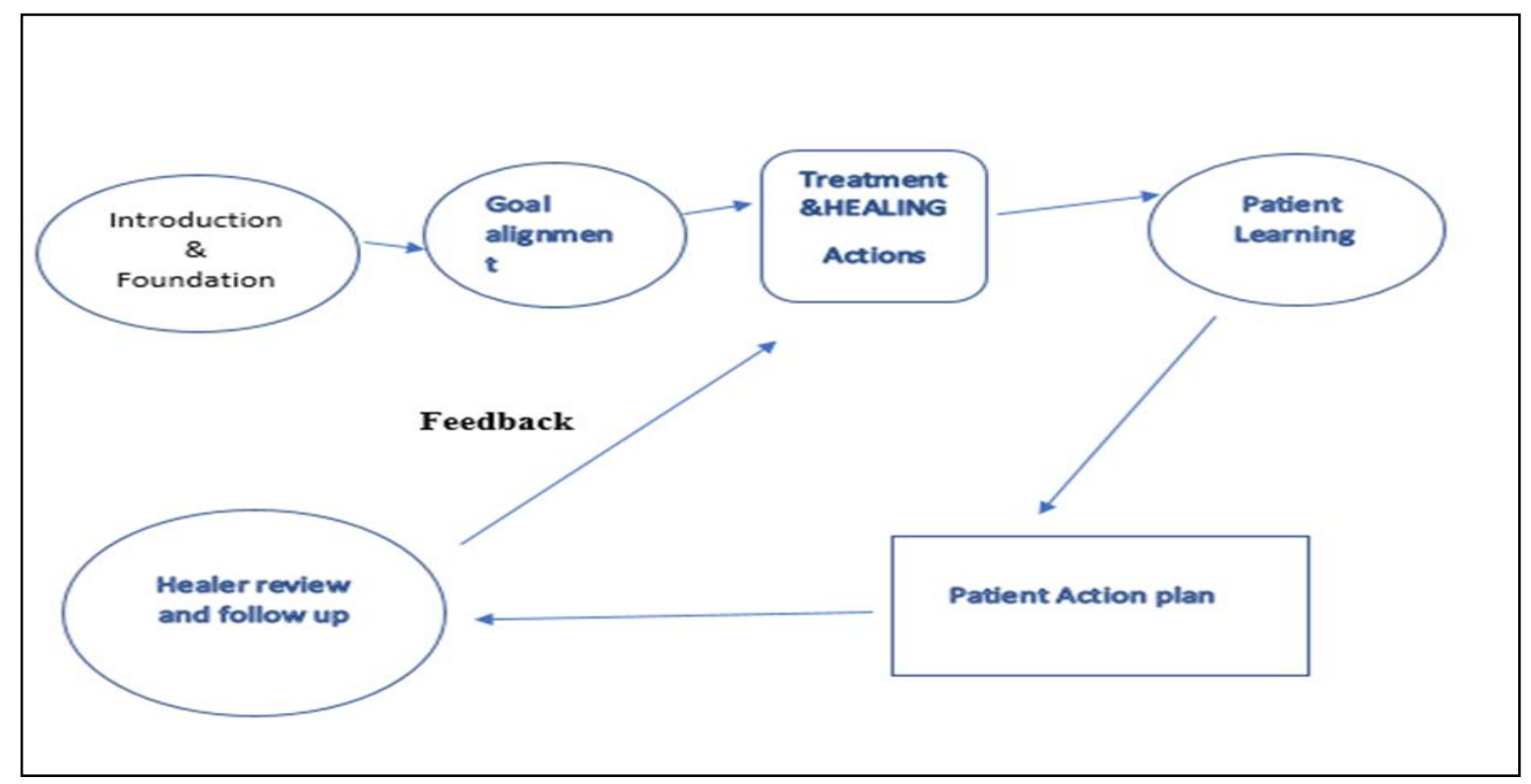

Figure 5. A process model for action by the practitioners and patients

The process model shown in figure 5 gives a picture of the stages involved in the healing treatment of patients, and used by all healers consistently.

\subsection{Data Collection}

The medical parameters measured, and diagnostic criteria to identify diabetes specified by the American Diabetes Association (ADA) include the following (Christensen, 2018)

- A fasting plasma glucose (FPG) level of $126 \mathrm{mg} / \mathrm{dL}(7.0 \mathrm{mmol} / \mathrm{L})$ or higher, or

- A 2-hour plasma glucose level of $200 \mathrm{mg} / \mathrm{dL}$ (11.1 mmol/L) or higher during a 75-g oral glucose tolerance test (OGTT), or

- A random plasma glucose of $200 \mathrm{mg} / \mathrm{dL}(11.1 \mathrm{mmol} / \mathrm{L})$ or higher in a patient with classic symptoms of hyperglycemia or hyperglycemic crisis

Additionally, a hemoglobin A1C (HbA1c) test measures the amount of blood sugar (glucose) attached to hemoglobin. Hemoglobin is the part of human red blood cells that carries oxygen from lungs to the rest of our body. An HbAlc test shows what the average amount of glucose attached to hemoglobin has been over the past three months. It is a three-month average because that is typically how long a red blood cell lives. HbA1c results are given in percentages. Typical results are as given below (Medlineplus, 2018).

Normal: HbA1c below $5.7 \%$

Prediabetes: HbA1c between $5.7 \%$ and 6.4

Diabetes: HbA1c of $6.5 \%$ or higher

The American Diabetes Association recommends keeping HbA1c levels below 7\%. Health care providers may make other recommendations for patients, depending on their overall 


\section{Macrothink}

health, age, weight, and other factors.

The above stated guidelines are used in the data collection and analysis in this study. From the available data on blood sugar test reports collected over three years of YPV healing camps available at the YPV Ashram, Table 1 shown below illustrates the 19 cases taken up for this analysis. In the YPV healing camps conducted, patients with various ailments walk in and the camps do not target specific ailment. That is the reason for taking the data of 19 diabetic patients available which is used in this study.

For reasons of ethics and participants' confidentiality, the names of the patients are given in code names only and healers' names also are not revealed in this report. Further, the healers were asked about the time they generally engage the patients in course of treatment, from introductory sessions to healing sessions and final outcome. Various actions they perform are also considered in the overall process.

Table 1. Cases of YPV healings done to treat Diabetes Type 2

\begin{tabular}{|c|c|c|c|c|c|c|c|c|c|c|c|}
\hline \multirow[b]{2}{*}{ S. No } & \multirow[b]{2}{*}{$\begin{array}{l}\text { Date of } \\
\text { Treatment }\end{array}$} & \multirow[b]{2}{*}{$\begin{array}{l}\text { patient } \\
\text { code } \\
\text { name }\end{array}$} & \multirow[b]{2}{*}{$\begin{array}{l}\text { age - } \\
\text { years }\end{array}$} & \multirow[b]{2}{*}{ gender } & \multirow{2}{*}{$\begin{array}{l}\text { healing } \\
\text { techniq } \\
\text { ue }\end{array}$} & \multicolumn{6}{|c|}{ Table 1: Cases of YPV healings done to treat Diabetes Type 2} \\
\hline & & & & & & $\begin{array}{l}\text { Healing Session } \\
\text { Duration per day } \\
\mathrm{X} \text { days }\end{array}$ & pre-treatment condition & post treatment & $\begin{array}{l}\text { b/f healing } \\
\text { report date }\end{array}$ & $\begin{array}{l}\text { a/f healing } \\
\text { report date }\end{array}$ & $\begin{array}{l}\text { assessment } \\
\text { after }\end{array}$ \\
\hline 1 & 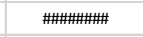 & P1 & 56 & male & HDP L1 & $30-40 \mathrm{~min} \times 06 \mathrm{~d}$ & FBS-150.0 mg/dl PPBS-290.0mg/dl & FBS $142.0 \mathrm{mg} / \mathrm{dl}$ PPBS- $192.0 \mathrm{mg} / \mathrm{dl}$ & 05-04-2017 & 09-08-2017 & 4 months \\
\hline 2 & 20-12-2016 & De & 50 & female & & $30-40 \mathrm{~min} \times 06 \mathrm{~d}$ & RBS-372.0mg/dl & RBS $201.0 \mathrm{mg} / \mathrm{dl}$ & $15-12-2016$ & 01-03-2017 & $21 / 2$ months \\
\hline 3 & 25-08-2016 & $\mathrm{Ka}$ & 70 & female & & $30-40 \mathrm{~min} \times 70 \mathrm{~d}$ & RBS-196mg/dl & RBS $166 \mathrm{mg} / \mathrm{dl}$ & $09-08-2016$ & $12-10-2016$ & 2 months \\
\hline 4 & $18-09-2016$ & $\mathrm{J1}$ & 48 & female & & $30-40 \mathrm{~min} \times 75 \mathrm{~d}$ & FBS-172 mg/dl PPBS-260mg/dl & FBS-139.0 mg/dl PPBS- $155.0 \mathrm{mg} / \mathrm{dl}$ & 10-09-2016 & $12-09-2016$ & 2 days \\
\hline 5 & \#\#\#\#\#\# & Ko & 54 & female & & $30-40 \mathrm{~min} \times 50 \mathrm{~d}$ & FBS-133 mg/dl PPBS-166mg/dl & FBS-123mg/dl PPBS-142mg/dl & 07-Aug-16 & 30-Nov-16 & $41 / 2$ months \\
\hline 6 & $25-09-2016$ & M1 & 49 & female & & $30-40 \mathrm{~min} \times 70 \mathrm{~d}$ & FBS-131 mg/dl PPBS-208mg/dl & FBS-108mg/dl PPBS- $165 \mathrm{mg} / \mathrm{dl}$ & 24-09-2016 & $12-02-2017$ & $41 / 2$ onths \\
\hline 7 & \#\#\#\#\#\# & $\mathrm{J} 2$ & 60 & male & & $30-40 \mathrm{~min} \times 30 \mathrm{~d}$ & FBS-213mg/dl PPBS-262mg/dl & FBS-82mg/dl PPBS-130mg/dl & $11-09-2016$ & $12-09-2016$ & 1 day \\
\hline 8 & $30-09-2016$ & $\mathrm{Dh}$ & 75 & female & & $30-40 \mathrm{~min} \times 10 \mathrm{~d}$ & FBS- $215 \mathrm{mg} / \mathrm{dl}$ PPBS- $425 \mathrm{mg} / \mathrm{dl}$ & FBS-93mg/dl PPBS-109mg/dl & $27-04-2013$ & $28-09-2016$ & 5 months \\
\hline 9 & 30-09-2017 & $\mathrm{Vi}$ & 85 & male & & $30-40 \min \times 10 \mathrm{~d}$ & PPBS-207mg/dl & FBS- $117 \mathrm{mg} / \mathrm{dl}$ PPBS- $142 \mathrm{mg} / \mathrm{dl}$ & 23-07-2016 & $28-09-2016$ & 2 months \\
\hline 10 & $22-12-2016$ & R1 & & female & & $30-40 \mathrm{~min} \times 10 \mathrm{~d}$ & FBS-158mg/dl PPBS-218MG/DL & FBS-145mg/dl PPBS-223mg/dl & $21-12-2016$ & $30-12-2016$ & 1 week \\
\hline 11 & \#\#\#\#\#\# & $\mathrm{Da}$ & 74 & female & & $30-40 \min \times 9 d$ & FBS-144.3mg/d PPBS-206.4MG/DL & FBS-133.9mg/dl PPBS-159.4mg/dl & $28-08-2016$ & $13-12-2016$ & $31 / 2$ months \\
\hline 12 & 25-09-2016 & N1 & 70 & female & & $30-40 \mathrm{~min} \times 20 \mathrm{~d}$ & FBS-149.0mg/dl PPBS-231.3mg/dl & FBS-122mg/dl PPBS-164mg/dl & $20-09-2016$ & $10-04-2017$ & $61 / 2$ months \\
\hline 13 & $27-08-2016$ & N2 & 58 & male & & $30-40 \mathrm{~min} \times 05 \mathrm{~d}$ & FBS-220mg/dl PPBS-301mg/dl & FBS-102mg/dl PPBS-268mg/dl & $27-08-2016$ & $15-09-2016$ & 18 days \\
\hline 14 & \#\#\#\#\#\# & M2 & 74 & male & & $30-40 \mathrm{~min} \times 05 \mathrm{~d}$ & Fasting glucose $-144 \mathrm{mg} / \mathrm{dl}$ & Fasting glucose- $-109 \mathrm{mg} / \mathrm{dl}$ & $19-07-2016$ & 02-08-2016 & 14 days \\
\hline 15 & $18-06-2016$ & $u$ & 61 & male & & $30-40 \mathrm{~min} \times 30 \mathrm{~d}$ & FBS-260mg/dl PPBS-416mg/dl & \multicolumn{3}{|l|}{ FBS- $120 \mathrm{mg} / \mathrm{dl}$ PPBS-226mg/dl } & \\
\hline 16 & $17-10-2013$ & s & 50 & female & & $30-40 \mathrm{~min} \times 30 \mathrm{~d}$ & FBS- $380 \mathrm{mg} / \mathrm{dl}$ PPBS-496mg/dl & FBS-94mg/dl PPBS-139mg/dl & 16-Oct-13 & 22-Nov-13 & 1 month \\
\hline 17 & $30-04-2017$ & M3 & 62 & female & & $30-40 \mathrm{~min} \times 30 \mathrm{~d}$ & FBS-304.6mg/dl PPBS-402.8mg/dl & FBS-131.9mg/dl PPBS-91.0mg/dl & $25-04-2017$ & $30-05-2017$ & 1 month \\
\hline \multirow[t]{2}{*}{18} & \#\#\#\#\#\# & $\mathrm{J3}$ & 64 & Male & & Rhythmic breathir & if FBS $174 \mathrm{mg} / \mathrm{dl} \quad \mathrm{HbA} 1 \mathrm{C} 7.0 \%$ & FBS $132 \mathrm{mg} / \mathrm{dl} \quad$ HbA1C 6.0 & 16-03-2016 & $20-10-2016$ & 7 months \\
\hline & & & & & & healing daily & \multicolumn{4}{|c|}{ T3 124.3 ng/dl T4 9.1microg/dl TSH 7.43microlU } & \\
\hline \multirow[t]{4}{*}{19} & & $\mathrm{Ki}$ & 55 & Female & & Salt free food & Liver Enlarged 17.17+2.1 Fatty liver de ! & \multicolumn{2}{|c|}{ Normal liver in size and echo textu1 15-03 16} & $18-10-2016$ & 7 months \\
\hline & & & & & & & FBS $120 \mathrm{ng} / \mathrm{dl}$ PPBS $134 \mathrm{ng} / \mathrm{dl}$ HbA1C $6.3 \%$ & \multicolumn{3}{|c|}{ FBS $84 \mathrm{ng} / \mathrm{dl}$ PPBS $97 \mathrm{ng} / \mathrm{dl}$ HbA1C $5.0 \%$} & \\
\hline & & & & & & & & & & & \\
\hline & & & & & & & & & & & \\
\hline
\end{tabular}




\section{Mll Macrothink}

Table 2. Comparative Analysis of data pre -YPV vs. Post - YPV

\begin{tabular}{|c|c|c|c|c|c|c|c|c|c|c|c|c|c|c|}
\hline & & & PRE YPV & Post YPV & & & PRE YPV & Post YPV & & & PRE YPV & Post YPV & & \\
\hline & & Ref $>$ & $100 / 125$ & $100 / 125$ & & & $140 / 200$ & $140 / 200$ & & & $<200$ & $<200$ & & \\
\hline S.No & Gender & Age & FBS & FBS & Change & Change $\%$ & PPBS & PPBS & Change & Change\% & RBS & RBS & Change & Change \% \\
\hline 1 & male & 56 & 150 & 142 & -8 & 5.3 & 290 & 192 & -98 & 33.7 & & & & \\
\hline 2 & female & 50 & & & & & & & & & 372 & 201 & -171 & $45.90 \%$ \\
\hline 3 & female & 70 & & & & & & & & & 196 & 166 & -30 & $15.30 \%$ \\
\hline 4 & female & 48 & 172 & 139 & -33 & 19.1 & 260 & 155 & -105 & 40.38 & & & & \\
\hline 5 & female & 54 & 133 & 123 & -10 & 7.5 & 166 & 142 & -24 & 14.4 & & & & \\
\hline 6 & female & 49 & 131 & 108 & -23 & 17.5 & 208 & 165 & -43 & 20.6 & & & & \\
\hline 7 & male & 60 & 213 & 82 & -131 & 61.5 & 262 & 130 & -132 & 50.3 & & & & \\
\hline 8 & female & 75 & 215 & 93 & 122 & 56.7 & 425 & 109 & -316 & 74.3 & & & & \\
\hline 9 & male & 85 & & & & & 207 & 143 & -64 & 30.9 & & & & \\
\hline 10 & female & & 158 & 145 & -13 & 8.2 & 218 & 223 & 5 incr & $><$ & & & & \\
\hline 11 & female & 74 & 144 & 133 & -11 & 7.6 & 206 & 159 & -47 & 22.8 & & & & \\
\hline 12 & female & 70 & 149 & 122 & -27 & 18.1 & 231 & 164 & -67 & 29.0 & & & & \\
\hline 13 & male & 58 & 220 & 102 & -118 & 53.6 & 301 & 268 & -33 & 10.9 & & & & \\
\hline 14 & male & 74 & 144 & 109 & -35 & 24.3 & & & & & & & & \\
\hline 15 & male & 61 & 260 & 120 & -140 & 53.8 & 416 & 226 & -190 & 45.67 & & & & \\
\hline 16 & female & 50 & 380 & 94 & -286 & 75.2 & 496 & 139 & -357 & 71.9 & & & & \\
\hline 17 & female & 62 & 304 & 131 & -173 & 56.9 & 402 & 91 & -311 & 77.3 & & & & \\
\hline 18 & Male & 64 & 174 & 132 & -42 & 24.1 & $\begin{array}{l}\text { HBA1C } \\
7\end{array}$ & HBA1C 6 & & & & & & \\
\hline \multirow[t]{2}{*}{19} & Female & 55 & 120 & 84 & -36 & 30 & 134 & 97 & -37 & 38.1 & & & & \\
\hline & & & & & & & $\begin{array}{l}\text { HBA1C } \\
6.3 \\
\end{array}$ & $\begin{array}{l}\text { HBA1C } \\
5 \\
\end{array}$ & & & & & & \\
\hline
\end{tabular}

\subsection{Data Analysis}

From the given demographic data, the age of the persons in this sample ranges from 48 to 85 . There were 7 males and 12 females as a representative sample of Type 2 Diabetes cases treated by 7 different healers. These 7 healers were all independent and carried out the healing independently at different times, using the same healing method as given in the standard procedure document HDP L1 of YPV System (YPV Ashram, 2018b). Table 2 shows the numerical analysis of the Fasting blood sugar (FBS), postprandial blood sugar (PPBS), Random blood sugar (RBS) and HBA1C of some patients. This study has not considered any gender specific factors in the analysis of this data.

\section{Results}

\subsection{Fasting Blood Sugar Analysis}

Processed data is presented in Table 2 and shown in the bar chart in Figure 6. From this, it is observed that the fasting blood sugar levels in respect of 17 patient records improved from diabetic condition to pre-diabetic for 6 patients, and to normal condition for 4 patients. In respect of the remaining 7 diabetic patients there is considerable reduction of glucose levels, encouraging to move forward with further treatment and improvement. 


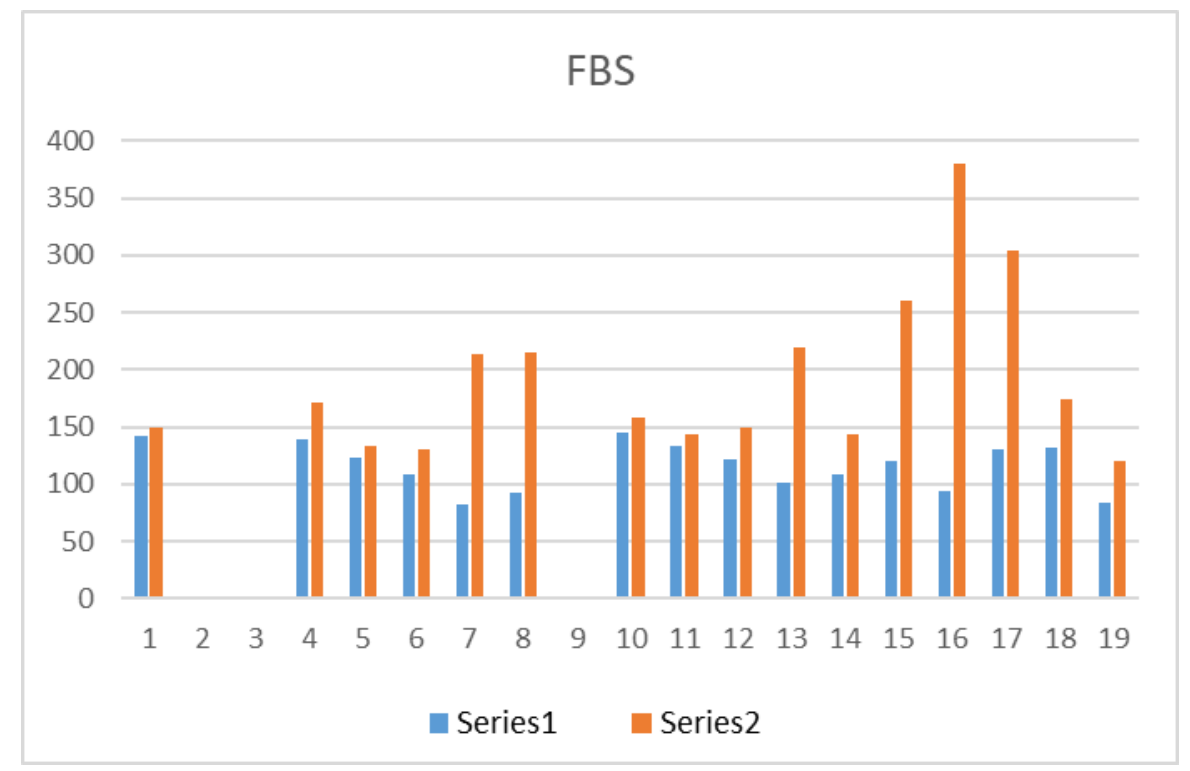

Figure 6. Bar chart showing levels of FBS before and after YPV intervention

(Legend: FBS levels are in $\mathrm{mg} / \mathrm{dl}$ units. Orange colour indicates measurement taken before YPV intervention, Blue colour indicates measurements taken after YPV intervention.)

\subsection{Postprandial Blood Sugar Levels}

From the processed data of the table 2, the bar chart in Figure 7 pictorially represents the improvements in the PPBS condition of 16 patient records available. However, one patient at S.No. 10 did not show any improvement in PPBS for reasons not known.

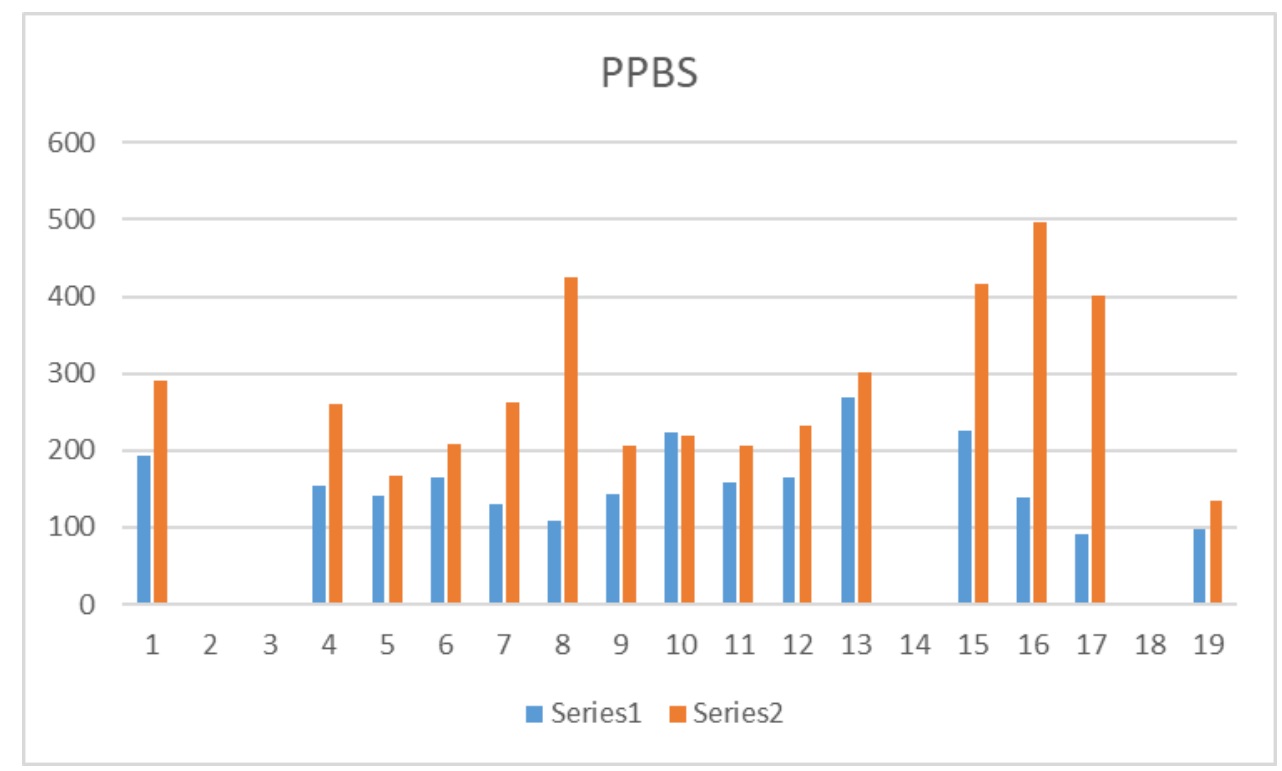

Figure 7. Bar chart showing levels of PPBS before and after YPV intervention

(Legend: PPBS levels are in mg/dl units. Orange indicates measurement taken before YPV intervention, Blue colour indicates measurements taken after YPV intervention.) 


\subsection{Random Blood Sugar}

Random blood sugar in respect of two patients recorded is shown in figure 8 showing very encouraging results for both of them.

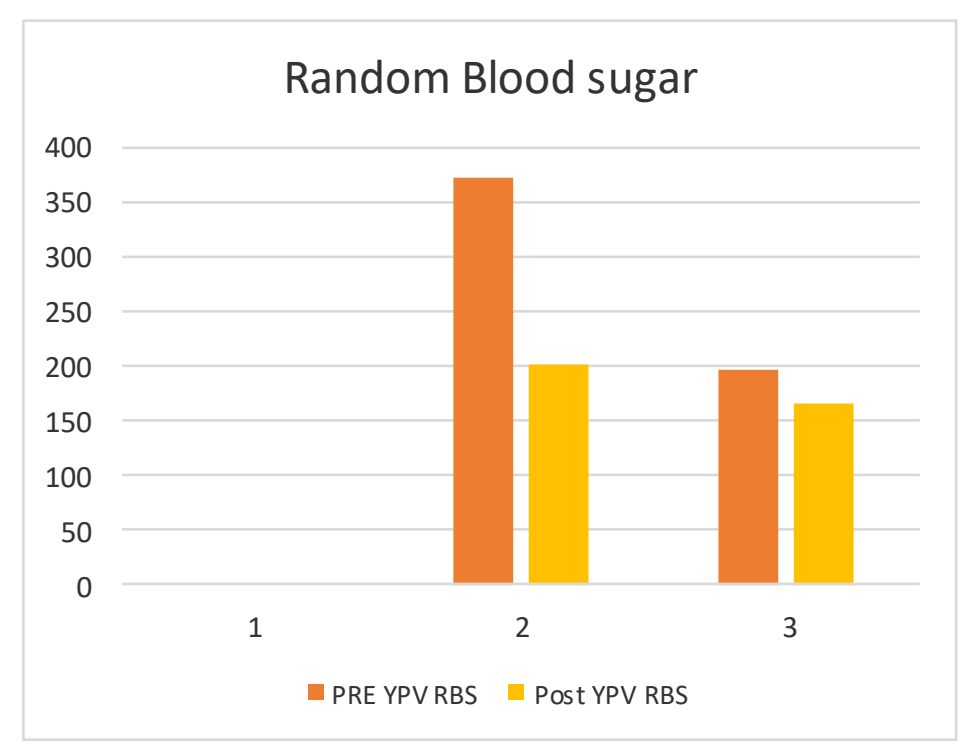

Figure 8. Bar chart showing levels of Random blood sugar before and after YPV Intervention.

(Legend: RBS levels are in $\mathrm{mg} / \mathrm{dl}$ units. Orange indicates measurement taken before YPV intervention, Blue colour indicates measurements taken after YPV intervention.)

4.4 HBA1c Results

The HemoglobinA1c results of two patient records are as shown in figure 9. It is observed that there is good improvement indicating normal condition for both after YPV treatment. 


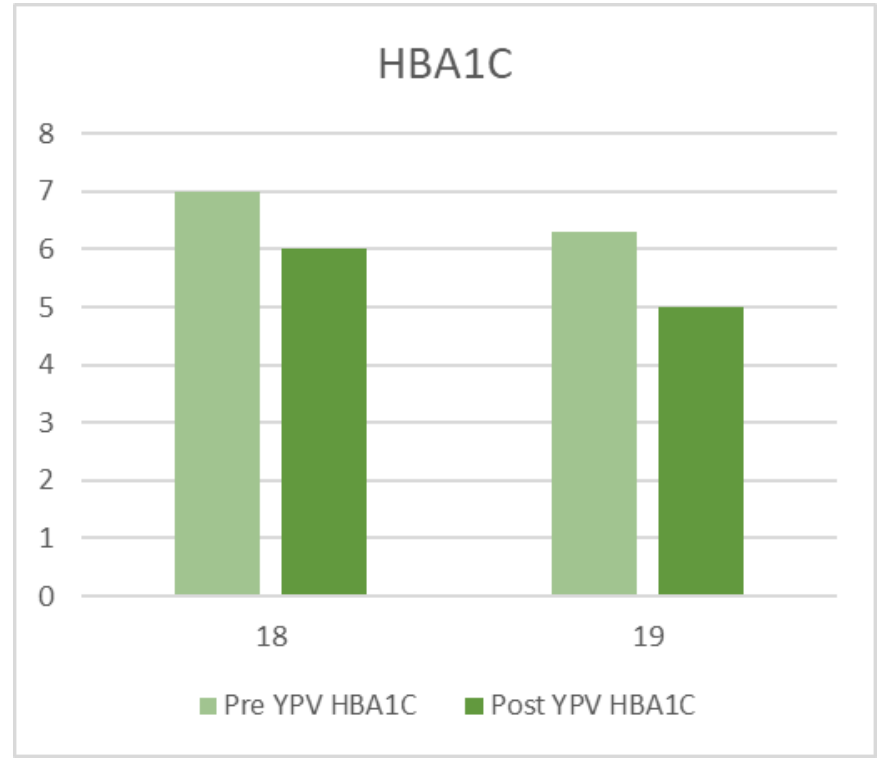

Figure 9. Bar chart showing levels of haemoglobin as percent before and after YPV intervention in case of two sample subjects

(Legend: HBA1C levels are in percentage units. Orange indicates measurement taken before YPV intervention, Blue colour indicates measurements taken after YPV intervention.)

\subsection{YPV Framework and Process Model}

This study has observed that consistent and satisfactory results of YPV healing treatments have been achieved by the healers practicing and maintaining the stages of the YPV system processes, as shown below in Table 3 .

Table 3. Process model stages

\begin{tabular}{|c|c|c|c|c|c|}
\hline 1 & 2 & 3 & 4 & 5 & 6 \\
\hline Introduction & $\begin{array}{l}\text { Goal } \\
\text { alignment } \\
\text { with healing } \\
\text { plan }\end{array}$ & $\begin{array}{l}\text { Series of } \\
\text { Healing } \\
\text { actions / } \\
\text { techniques }\end{array}$ & Learning & Action plan & $\begin{array}{l}\text { Follow up } \\
\text { Feedback } \\
\text { Review }\end{array}$ \\
\hline $\begin{array}{l}\text { Overview of } \\
\text { Values and } \\
\text { beliefs, } \\
\text { Healing goals, } \\
\text { Confidentiality } \\
\text { Trust building, }\end{array}$ & $\begin{array}{l}\text { Healer and } \\
\text { Patient } \\
\text { Jointly }\end{array}$ & $\begin{array}{l}\text { Healer } \\
\text { actions }\end{array}$ & $\begin{array}{l}\text { Patient } \\
\text { learns } \\
\text { self-practice }\end{array}$ & $\begin{array}{l}\text { Patient } \\
\text { oriented } \\
\text { action plan }\end{array}$ & $\begin{array}{l}\text { Ashram team } \\
\text { leaders } \\
\text { follow up } \\
\text { patients } \\
\text { periodically } \\
\text { and review } \\
\text { each case }\end{array}$ \\
\hline
\end{tabular}




\section{Discussion}

It is recognised that introductory and rapport building action of the healer would influence the healing process and outcomes (Neravetla, 2019). Clarity on the healing goals and aligning goals with the techniques is inbuilt in the healers' training programmes (Yoga Prana Vidya Research, 2019). It is considered important to follow up the treated patients over the phone or personally to know how they are able to sustain the changes and improvements with specified self-practices. This study recognizes that the YPV system of healing - treatment of Diabetes is a holistic and integrated process, with specified diet, exercise and meditation techniques which are easy to follow by the patients. This process leads to improved immunity and overall health by the natural reaction of the body. Besides Diabetes, other sicknesses such as BP, sleeplessness, anxiety and stress etc. have also been brought under control, with reduced drug dependency, as seen in patient feedbacks. In some cases the drug dependency was completely eliminated. The interrelation between healer and patient has also been found as an important factor in YPV practice. Being holistic and integrated system of treatment, YPV is a broader scope intervention, when compared with other therapies. As stated in the literature (Markus, Martin, Lisa v \& Bernhd, 2018), use of appropriate counselling and YPV psychological healing is also integral in the overall YPV system process for effective holistic treatment of diabetes. It is observed that in the given sample of patients treated for type 2 diabetes, there was appreciable reduction of blood sugar levels, indicating that primarily the targeted YPV healing framework was effective and worked well in treating diabetes.

\section{Conclusion}

This study has found primary evidence in the successful role of Yoga Prana Vidya (YPV) in management of Diabetes Type 2. Further, this study examined YPV healing practice tools and techniques used to treat diabetes cases, and identify the ingredients and steps applied by the practitioners in the process of treatment for desired results. YPV Framework and process model are constructed for use as tools for consistent use of practitioners for future rigorous clinical research to evaluate consistency of practice, and sustainability of patient results on longer term and larger scale; and foster evidence based practice of YPV healing. YPV system practice is establishing credibility in the treatment of diabetes and it is observed to be effective with seekers of non-drug treatment. It is recommended to conduct targeted research with various types of study designs to know more about any other factors that can influence YPV treatment of diabetes.

\section{Acknowledgements}

The authors express sincere thanks to the President, Sri Ramana trust for permission to conduct this study with access to patient records, and use its copyright terms of Yoga Prana Vidya (C) and YPV (C. 


\section{References}

Christensen, B. (2018). Type 2 Diabetes ADA Diagnosis criteria. [Online] Available https://emedicine.medscape.com/article/2172154-overview

Jonas, W., \& Crawford, C. C. (2003). Science and spiritual healing: A critical review of spiritual healing, "energy medicine" and intentionality. Alternative Therapies in Health and Medicine, 9(2), 56 -61.

Markus, S., Martin, N., Lisa, V. F., \& Bernhd, H. (2018). Alexithymia in Type 1 and Type II Diabetes. Interventions Obesity and Diabetes, 1(3).

https://doi.org/10.31031/IOD.2018.01.000512

Matheka, M. D., \& Demaico, A. R. (2013). Complementary and alternative medicine use among diabetic patients in Africa: A Kenyan Perspective. The Pan Africa Medical Journal, https://doi.org/10.11604/pamj.2013.15.110.2925

Medlineplus. (2018). Hemoglobin A1C Test. [Online] Available https://medlineplus.gov/lab-tests/hemoglobin-a1c-hba1c-test/

Neravetla, J. (2019). Role of Yoga Prana Vidya in First aid. Talk- Presentation at National workshop on first aid and emergency 18th April to 20th April, Yoga and Naturopathy Education Centre, Mahatma Gandhi Kashi Vidyapith, Varanasi, India

Neravetla, J., \& Nanduri, V. (2019). A study into successful treatment of some difficult Medical cases using Yoga Prana Vidya (YPV) Healing System as alternative medicine. International Journal of Science \& Engineering Research, Vol 10, Issue 7, July 2019. [Online] Available online https://www.ijser.org/research-paper-publishing-july-2019_page3.aspx

Research-Methodology.net. (2018). Exploratory Research. [Online] available https://research-methodology.net/research-methodology/research-design/exploratory-research / Retrieved on 10 October 2018.

Warber, S., Gordon, A., Gillespie, B. W., Olson, M., \& Assefi, N. (2003). Standards for conducting clinical Biofield Energy Healing Research. Alternative therapies in Health and Medicine, May/June 2003, 9(3), 54-64.

Wardha, H. (2004). Pranic healing. Australian Journal of Holistic Nursing, 2004 October, $11(2), 35-40$.

Yoga Prana Vidya Research. (2019). A compendium of Theory, Research and practice of Yoga Prana Vidya. Unpublished document, YPV Ashram, Sri Ramana Trust, Thally, Tamilnadu, India.

YPV Ashram. (2018a). YPV Healing levels 1, 2, 3 documents. YPV Ashram, Sri Ramana Trust, Thally, Tamilnadu, India

YPV Ashram. (2018b). YPV document HDP1, YPV Ashram document for Healers. YPV Ashram, Sri Ramana Trust, Thally, Tamilnadu, India 
Glossary

YPV

Yoga Prana Vidya

YOGA

Union of body, mind and soul with higher power

PRANA

Life-force or bio-plasmic energy

VIDYA

Knowledge

ASHRAM

Institution or establishment/abode

CHAKRAM

Energy Centre in the bio-plasmic body

SADHANA Practice

\section{Copyright Disclaimer}

Copyright for this article is retained by the author(s), with first publication rights granted to the journal.

This is an open-access article distributed under the terms and conditions of the Creative Commons Attribution license (http://creativecommons.org/licenses/by/3.0/). 